\title{
AT-Rich Interactive Domain-Containing Protein 1B
}

National Cancer Institute

\section{Source}

National Cancer Institute. AT-Rich Interactive Domain-Containing Protein 1B. NCI

Thesaurus. Code C102522.

AT-rich interactive domain-containing protein 1B (2236 aa, $\sim 236 \mathrm{kDa})$ is encoded by the human ARID1B gene. This protein plays a role in transcriptional regulation mediated by chromatin remodeling. 